\title{
Elevated level of ambient glucose stimulates the synthesis of high-molecular-weight hyaluronic acid by human mesangial cells. The involvement of transforming growth factor $\beta 1$ and its activation by thrombospondin-1
}

\author{
Natalia Yu. Yevdokimova ${ }^{\bowtie}$ \\ Palladin Institute of Biochemistry, National Academy of Sciences of Ukraine, Kyiv, Ukraine; \\ 凶e-mail: berezan@mathber.carrier.kiev.ua
}

Received: 20 November, 2005; revised: 21 February, 2006; accepted: 03 March, 2006

available on-line: 29 May, 2006

\begin{abstract}
The dysregulation of the metabolism of glycosaminoglycan and protein components of extracellular matrix (ECM) is a typical feature of diabetic complications. High glucose-induced enrichment of ECM with hyaluronan (HA) not only affects tissue structural integrity, but influences cell metabolic response due to the variety of effects depending on the HA polymer molecular weight. TSP-1-dependent activation of TGF 1 axis is known to mediate numerous matrix disorders in diabetes, but its role concerning HA has not been studied so far. In this work we demonstrated that $30 \mathrm{mM}$ D-glucose increased the incorporation of $\left.{ }^{3} \mathrm{H}\right]$ glucosamine in high-molecular-weight $(>2000 \mathrm{kDa}$ ) HA of medium and matrix compartments of human mesangial cultures. Simultaneously, the synthesis of HA with lower molecular weight and HA degradation were not altered. The cause of the increased high-molecular-weight HA synthesis consisted in the up-regulation of hyaluronan synthase (HAS) 2 mRNA without alterations of the expression of HAS3, which generates HA of lower molecular weight. D-Glucose at $30 \mathrm{mM}$ also stimulated the production of transforming growth factor $\beta 1$ (TGF $\beta 1$ ), the excessive activation of which was determined by the up-regulation of thrombospondin-1 (TSP-1). The blockage of TGF $\beta 1$ action either by neutralizing anti-TGF $\beta 1$ antibodies or by quenching the TGF $\beta 1$ activation (with TSP-1-derived synthetic GGWSHW peptide) abolished the effect of high glucose on HAS2 mRNA expression and normalized the synthesis of HA. Exogenous human TGF $\beta 1$ had the same effect on HAS2 expression and HA synthesis as high glucose treatment. Therefore, we supposed that TSP-1-dependent TGF $\beta 1$ activation is involved in the observed high glucose effect on HA metabolism. Since high-molecular-weight HA polymers, unlike middle- and low-molecular weight HA oligosaccharides, are known to possess anti-inflammatory and anti-fibrotic functions, we suppose that the enrichment of mesangial matrix with high-molecular-weight HA may represent an endogenous mechanism to limit renal injury in diabetes.
\end{abstract}

Keywords: high glucose, hyaluronic acid, mesangial cells, transforming growth factor $\beta 1$, thrombospondin-1

\section{INTRODUCTION}

Expansion of the glomerular mesangial matrix is a typical feature of diabetic nephropathy, and the elevated blood glucose level is considered to be the main cause of this phenomenon. Numerous in vivo and in vitro investigations indicated that high ambient glucose level induces dysregulation of the metabolism of the extracellular matrix (ECM) and excessive protein accumulation (McLennan et al., 1999).

$\star$ Preliminary results were presented at the 43rd Meeting of the European Tissue Culture Society, September, 2001, Granada, Spain and at the XX Congress of the International Society of Thrombosis and Haemostasis, August, 2005, Sydney, Australia.

Abbreviations: ECM, extracellular matrix; GAPDH, glyceraldehyde-3-phosphate dehydrogenase; HA, hyaluronic acid; HAS, hyaluronan synthase; HMCs, human mesangial cells; HMW, high molecular weight; ITS, insulin, transferrin, sodium selenite; LMW, low molecular weight; MMW, middle molecular weight; PTC, proximal tubular epithelial; TGF $\beta 1$, transforming growth factor $\beta 1$; TSP-1, thrombospondin-1; W-peptide, synthetic GGWSHW peptide; Y-peptide, synthetic GGYSHW peptide. 
Besides, it has been shown that elevated level of ambient glucose modulates also the metabolism of nonprotein components of mesangial matrix, and, in particular, stimulates the accumulation of hyaluronic acid (HA). Previous works demonstrated increased HA content in glomeruli of diabetic animals (Mahadevan et al., 1995), in high glucose-treated rat mesangial cells (Dunlop et al., 1996; Wang \& Hascall, 2004) and in other cell types responsible for normal physiology of kidney (Jones et al., 2001; Takeda et al., 2001). It seems that the effect of elevated glucose level on HA metabolism in mesangial cells has been studied insufficiently, especially taking into account not only the HA role in tissue structural integrity, but its various metabolic effects, which are determined by the polymer molecular weight (Noble, 2002).

In almost all kidney cell types, and in mesangial cells, in particular, high glucose up-regulates the expression and activity of transforming growth factor- $\beta 1$ (TGF $\beta 1$ ). It is known that virtually all mediators and signaling pathways that have been shown in diabetic nephropathy have also been identified as stimulators of TGF $\beta 1$ up-regulation. The blocking of TGF $\beta 1$ action by various approaches evidently attenuates the high glucose-induced increase of matrix expression, demonstrating that TGF $\beta 1$ is the major mediator of this pathological phenomenon (Ziyadeh, 2004).

The implication of TGF $\beta 1$ in high glucose-induced alterations of HA metabolism has been demonstrated only for renal intestinal fibroblasts (Takeda et al., 2001), and Wang and Hascall (2004) gave a hint at a possible participation of TGF $\beta 1$ in increased HA production by rat mesangial cells treated with high glucose. However, TGF $\beta 1$ is known modulator of HA metabolism in various cell types (Heldin et al., 1989; Haubeck et al., 1995; Breborowich et al., 1996; Ellis \& Schor, 1998; Sugiyama et al., 1998; Usui et al., 2000; Reckleis et al., 2001), hence the participation of TGF $\beta 1$ in high glucose-induced increase of HA production by mesangial cells seems to be likely.

And, finally, TGF $\beta 1$ is secreted in a latent form by virtually all cells, and the changes in its expression will have no biological effect unless mechanisms of its activation are operational (Hugo, 2003). TGF $\beta 1$ may be activated in various ways, including proteolysis of the complex which determines latency. However, at high glucose conditions the likelihood of this way of activation is reduced because of the reduced activity of the main enzymes involved in TGF $\beta 1$ activation.

As to mesangial cells, it was demonstrated that in high-glucose conditions the activation of TGF 1 1 (and, therefore, the accumulation of matrix proteins) is realized by the action of endogenous thrombospondin-1 (TSP-1), the production of which is increased at high glucose conditions (Poczatek et al., 2000; Yevdokimova et al., 2001). Moreover, TSP1 is believed to be the main physiological activator of endogenous TGF $\beta$ in various cells and tissues (Crawford et al., 1998; Hugo, 2003). However, the role of TSP-1-dependent TGF $\beta 1$ activation with respect to HA metabolism has not been studied.

Thus, it was of interest to ascertain that an elevated level of ambient glucose stimulates the production of HA by human mesangial cells and, in case of positive results, to verify the supposed participation of TGF $\beta 1$ and its activation by TSP-1 in the mediating of high glucose effect on HA metabolism.

To this aim we (a) investigated the incorporation of a radioactive precursor of HA into medium, matrix and cell-associated compartments of mesangial cultures, treated with elevated glucose; (b) studied the molecular size distribution of labeled HA in all compartments, and compared the capacity of mesangial cells to degrade exogenously added HA at normal and elevate glucose levels; (c) determined the level of TGF $\beta 1$ secretion and activation, and the secretion of TSP-1 at high glucose conditions; (d) investigated the effects of a TGF $\beta 1$ neutralizing antibody, synthetic TSP-derived GGWSHW peptide (which is known to stop TSP-dependent TGF $\beta 1$ activation), and exogenous TGF $\beta 1$ on HA metabolism; (g) determined the expression of mRNA for hyaluronan synthases (HAS1, HAS2 and HAS3) in human mesangial cells and studied the effect of high glucose, GGWSHW peptide and exogenous TGF $\beta 1$ on mRNA expression of these enzymes.

\section{MATERIALS AND METHODS}

Materials. Primary normal human mesangial cells (HMC; CC-2259, lot 8F1498) were purchased from BioWhittaker (Walkersville, MD, USA). Fetal calf serum (FCS) was from Gibco BRL (Paisley, UK). RPMI 1640 medium without D-glucose, EMEM and DMEM medium with Glutamax, ITS (insulin, transferrin, sodium selenite), non-essential amino acids, antibiotics, glutamine, D-glucose, bovine serum albumin, trypsin, soybean trypsin inhibitor, heparitinase I, hyaluronate lyase from Streptomyces hyalurolyticus, pronase E, monoclonal mouse anti-TSP-antibody, 3-[(3-cholamidopropyl)dimethylammonio]-1-propanesulphonate (CHAPS), blue dextran calibration standard and decorin were from Sigma-Aldrich (Dorset, UK, and Schnelldorf, Germany). Monoclonal mouse anti-TGF $\beta 1$ antibody, recognizing human TGF $\beta 1$ and TGF $\beta 2$, were from Genzyme (Minneapolis, MN, USA). Hyaluronic acid-K-salt was from Fluka Chemical Corp. (Milwaukee, WI, USA), HEALON GV from Pharmacia \& Upjohn (Stock- 
holm, Sweden), DEAE-cellulose was from Serva (Heidelberg, Germany). Sephacryl S-1000 and D-[1$\left.{ }^{3} \mathrm{H}\right]$ glucosamine $(7.20 \mathrm{Ci} / \mathrm{mmol} \mathrm{sp}$. act.) were from Amersham Pharmacia Biotech (Uppsala, Sweden). Human TGF $\beta 1$ and TGF $\beta 1$ determination immunoassay kit were from R\&D Systems (Minneapolis, MN, USA). Human platelet TSP-1 was from Calbiochem-Novabiochem (La Jolla, CA, USA). Secondary peroxidase-conjugated rabbit anti-mouse antibody was from DAKO (High Wycombe, UK). RNAzolB was from AMS Biotechnology (Oxfordshire, UK). RT-PCR kits and 1-kb DNA ladder were supplied by Life Technologies (Gibco BRL, Paisley, UK) and primers by PE-Applied Biosystems (Cheshire, UK). Both the GGWSHW peptide and the control GGYSHW peptide were synthesized in the Advanced Biotechnology Center of Imperial College (London, UK). All other chemicals used were of the highest quality available.

Cell culture. Primary human mesangial cells (HMCs) were maintained at $37^{\circ} \mathrm{C}$ with $5 \% \mathrm{CO}_{2} / 95 \%$ air in RPMI 1640 medium, containing $4 \mathrm{mM}$ glucose, $10 \%$ FCS, $2 \mathrm{mM}$ glutamine, $100 \mu \mathrm{g} / \mathrm{ml}$ streptomycin, $100 \mathrm{U} / \mathrm{ml}$ penicillin, $1 \mu \mathrm{g} / \mathrm{ml}$ amphotericin B, and ITS (insulin, transferrin and sodium selenite at $5 \mu \mathrm{g} / \mathrm{ml}$, $5 \mu \mathrm{g} / \mathrm{ml}, 5 \mathrm{ng} / \mathrm{ml}$, respectively,). Cells were routinely passaged with 1:4 split and were used for experiments at the 7 th to 9 th passages.

Mink lung epithelial (MvILu) cells were grown in DMEM with Glutamax, supplemented with $10 \%$ FCS and antibiotics (as above). MvILu cells were passaged with $1: 10$ split at $80 \%$ confluence.

Human dermal fibroblast culture was initiated in the laboratory by the explant method. The secondary culture was maintained in EMEM supplemented with $10 \%$ FCS, $2 \mathrm{mM}$ glutamine, antibiotics (as above), 1\% non-essential aminoacids, and subcultured (1:6) every 5-6 days.

Metabolic labeling and analysis of HA. The determination of $\left[{ }^{3} \mathrm{H}\right]$ glucosamine incorporation into HA was carried out as described (Yevdokimova, 2003) Briefly, at the end of incubation, the conditioned medium was aspirated. Cell layers were washed; the wash and medium were combined and designated as a medium (secreted) fraction. Cell layers were processed with $0.025 \%$ trypsin $/ 0.01 \%$ EDTA, the cells were resuspended and aspirated, the flask was washed with $0.05 \%$ trypsin inhibitor, and the cell suspension was combined with wash liquid and centrifuged. The supernatant (trypsinreleased material) was designated as a pericellular matrix fraction, whereas the pellet was designated as a cell-associated one. All fractions were digested with pronase $\mathrm{E}\left(1.5 \mathrm{mg} / \mathrm{ml}, 18 \mathrm{~h}, 50^{\circ} \mathrm{C}\right)$, dialyzed, and applied onto DEAE-cellulose columns. Elution was carried out with $0.10 \mathrm{M}$ and $0.28 \mathrm{M} \mathrm{NaCl}$, as described previously (Yevdokimova \& Freshney,
1997). The material eluted with $0.10 \mathrm{M} \mathrm{NaCl}$, is the residual glycoproteins, and they were discarded. HA was eluted with $0.28 \mathrm{M} \mathrm{NaCl}$, precipitated with ethanol (the final concentration $75 \% \mathrm{v} / \mathrm{v}$ ) and dissolved in water. Aliquots were used for the determination of tritium radioactivity. The identification of $\left[{ }^{3} \mathrm{H}\right] \mathrm{HA}$ was carried out by enzyme degradation of the material after its desalting and concentration on a Centriprep-3 with consequent gel-filtration on Sephadex G-50 and radioactive determination. Material sensitive to hyaluronate lyase (EC 4.2.2.1) and insensitive to heparitinase I (EC 4.2.2.8) was designated as HA. Samples with $\left[{ }^{3} \mathrm{H}\right] \mathrm{HA}$ material were combined, precipitated with ethanol, dissolved in $0.2 \mathrm{ml} 100 \mathrm{mM}$ Na-acetate, $10 \mathrm{mM} \mathrm{NaCl}, 0.025 \%$ CHAPS, pH 6.5, and used for the analysis of molecular size distribution. Two samples with similar material $\left(\left[{ }^{3} \mathrm{H}\right] \mathrm{HA}\right.$ of medium, matrix or cell-associated fractions from cultures treated with $4 \mathrm{mM}$ or $30 \mathrm{mM}$ glucose) were combined and chromatographed on Sephacryl S1000 column $(1 \times 30 \mathrm{~cm})$. Elution was carried out at $12 \mathrm{ml} / \mathrm{h}$ with the same buffer, and fractions of 0.5 $\mathrm{ml}$ were collected. In the initial experiments the material of all fractions was verified with hyaluronate lyase and heparitinase I digestion. The column was calibrated with (a) Healon GV (7000 kDa), (b) blue dextran $(2000 \mathrm{kDa}),(\mathrm{c})$ decorin $(100 \mathrm{kDa})$ and $(\mathrm{d})$ $\left[{ }^{3} \mathrm{H}\right]$ glucosamine hydrochloride (215 Da).

Degradation of exogenous $\left[{ }^{3} \mathrm{H}\right] \mathrm{HA}$ by HMCs. Human skin fibroblasts were used to prepare $\left[{ }^{3} \mathrm{H}\right] \mathrm{HA}$ which was then added to HMC cultures. Fibroblasts were grown to confluence in T75 flasks and incubated with $\left[{ }^{3} \mathrm{H}\right]$ glucosamine for 72 $h$ in serum-free EMEM. The conditioned medium was removed, $\left[{ }^{3} \mathrm{H}\right] \mathrm{HA}$ was isolated and analyzed, as above. After Sephacryl S-1000 chromatography, HA was pooled according to its radioactive profile. The fractions corresponding to high-molecular-weight (HMW) HA (>2000 kDa) were dialyzed repeatedly against serum-free RPMI 1640 medium. Three milliliters of RPMI 1640 medium, supplemented with 4 or $30 \mathrm{mM}$ glucose, containing approx. 250000 d.p.m. of $\left[{ }^{3} \mathrm{H}\right] \mathrm{HA}$ were added to HMCs, which had been incubated with 4 or $30 \mathrm{mM}$ glucose, respectively. After $24 \mathrm{~h}$ or $72 \mathrm{~h}$ the conditioned medium fraction was removed and analyzed, as above.

Determination of secreted TSP-1, and total and active TGF $\beta 1$. At the end of incubation period the conditioned medium was collected under sterile conditions and centrifuged $(3000 \times g, 10 \mathrm{~min})$. To the samples, assigned to the determination of TSP1 , protease inhibitors were added to final concentrations of $10 \mathrm{mM}$ aminohexanoic acid, $1 \mathrm{mM}$ EDTA, $5 \mathrm{mM}$ benzamidine, $1 \mathrm{mM}$ phenylmethylsulphonyl fluoride, and $1 \mathrm{mM}$-ethylmaleimide. Samples were stored at $-70^{\circ} \mathrm{C}$ before assay. The determination of TSP-1 was performed by ELISA, as described previ- 
ously (Yevdokimova et al., 2001). The optimal dilution of primary and secondary antibodies was found to be 1:1000. The bound antibodies were detected with 2,2'-azinobis-3-ethylbenzthazoline-6-sulphonic acid at $405 \mathrm{~nm}$.

Total and active TGF $\beta 1$ levels were determined using the MvILu cell growth inhibition assay as described (Yevdokimova et al., 2001). MvILu cells were seeded at 7-10 $\times 10^{4}$ cells $/ \mathrm{ml}$ in 96-well plates in DMEM with $10 \%$ FCS. After $2-3 \mathrm{~h}$ the plates were washed, and HMCs-conditioned medium $(100 \mu \mathrm{l})$ and DMEM with $10 \%$ FCS $(100 \mu \mathrm{l})$ were added to the wells. To measure total TGF $\beta 1$, conditioned medium samples were heat-activated for $10 \mathrm{~min}$ at $80^{\circ} \mathrm{C}$. After 3 days the number of cells was determined by sulphorodamine $\mathrm{B}$ assay. A standard curve was constructed for $1 \times 10^{4}-30 \times 10^{4}$ cells. A further standard curve was set up for each assay with 0.01 to $1 \mathrm{ng} /$ $\mathrm{ml}$ of human platelet TGF $\beta 1$. Specificity of the assay was proven by ELISA determination of TGF $\beta 1$.

RT-PCR. Cell layers $\left(4.5-5 \times 10^{5}\right.$ cells) were washed extensively with phosphate-buffered saline at $4^{\circ} \mathrm{C}$ and solubilized in RNAzolB. Total RNA were extracted, dissolved in diethyl pyrocarbonate-treated water, and stored at $-70^{\circ} \mathrm{C}$ before assay. RNA was quantified by the absorbance at 260 and $280 \mathrm{~nm}$. The samples showed $A_{260} / A_{280} \geq 1.8$.

Equal amounts $(2 \mu \mathrm{g})$ of DNA-free total RNA from each sample were converted to cDNA by SuperScriptTM II RNase H-reverse transcriptase with random primers in a $20 \mu \mathrm{l}$ reaction volume. The reverse transcription reaction $(0.5 \mu \mathrm{l})$ was subjected to PCR amplification, using $2.5 \mathrm{U}$ of Taq DNA polymerase in $100 \mu \mathrm{l}$ reaction volume with $0.5 \mu \mathrm{M}$ of each dNTP, $0.5 \mu \mathrm{M}$ of each specific primer, and $1.5 \mathrm{mM} \mathrm{MgCl}_{2}$.

The sequences of the primers were: HAS1 (497 bp): 5'-GCG GGC TTG TCA GAG CTA-3' - forward, 5'-AGA GCG AGA GAA GCA CCA-3' - reverse; HAS2 (398 bp): 5'-GTG ATG ACA GGC ATC TCA-3' - forward, 5'-GCG GGA AGT AAA CTC GA-3' - reverse; HAS3 (450 bp): 5'-CAG CCT GCA CCA TCG A-3' - forward, 5'-AGA GGT GGT GCT TAT GGA-3' - reverse (Stuhlmeier \& Pollaschek, 2004). We co-amplified the house-keeping gene of glyceraldehyde-3-phosphate dehydrogenase (GAPDH) to allow semi-quantificative comparison of PCR products and to confirm the equal usage of mRNA. GAPDH (195 bp): 5'-TGA TGA CAT CAA GAA GGT GGT GAA G-3' - forward, 5' GAG GCC ATG TGG GCC AT-3' - reverse.

The amount of reverse-transcribed cDNA $(0.5 \mu \mathrm{l})$ used for amplification was determined to be nonsaturating for the PCR product of all genes under investigation. Amplification was started with $3 \mathrm{~min}$ of denaturation at $94^{\circ} \mathrm{C}$ followed by $33 \mathrm{PCR}$ cycles. Each cycle consisted of $60 \mathrm{~s}$ at $94^{\circ} \mathrm{C}, 60 \mathrm{~s}$ at $62^{\circ} \mathrm{C}$ and $60 \mathrm{~s}$ at $72^{\circ} \mathrm{C}$. The final extension was for $10 \mathrm{~min}$ at $72^{\circ} \mathrm{C}$. After amplification, $10 \mu \mathrm{l}$ of each PCR reaction product was electrophoresed through a $1.2 \%(\mathrm{w} / \mathrm{v})$ agarose gel containing ethidium bromide $(0.5 \mu \mathrm{g} / \mathrm{ml})$. Gels were photographed, scanned and analyzed with Image software (NIH Image). The results were normalized to the intensity of the GAPDH bands.

Statistical analysis. Results were compared using unpaired $t$-test. $P$ values of $<0.05$ were regarded as significant.

\section{RESULTS}

For the experiments HMCs cells were plated at $4-5 \times 10^{3}$ cells $/ \mathrm{cm}^{2}$ in T25 flasks and grown to confluence (7-8 days). Confluent cultures of HMC were maintained at $4 \mathrm{mM}, 30 \mathrm{mM}$ glucose or $4 \mathrm{mM}$ glucose $+26 \mathrm{mM}$ mannitol (osmotic control) for 48 $\mathrm{h}$. For the first $24 \mathrm{~h}$ the medium was supplemented with $10 \%$ FCS, and then it was changed to a serum free one, supplemented with $500 \mathrm{ng} / \mathrm{ml}$ BSA and $10 \mu \mathrm{Ci} / \mathrm{ml}\left[{ }^{3} \mathrm{H}\right]$ glucosamine for the next $24 \mathrm{~h}$.

The cell density in confluent cultures of HMC maintained at different conditions showed no change over the incubation period and was $1.94 \pm 0.06 \times 10^{4}$ cells $/ \mathrm{cm}^{2}(\mathrm{n}=5)$ at the beginning of the experiment, $1.97 \pm 0.08 \times 10^{4} \mathrm{cells} / \mathrm{cm}^{2}(\mathrm{n}=12), 2.01 \pm 0.05 \times 10^{4}$ cells $/ \mathrm{cm}^{2}(\mathrm{n}=12)$ and $1.99 \pm 0.09 \times 10^{4}$ cells $/ \mathrm{cm}^{2}(\mathrm{n}=6)$ after $48 \mathrm{~h}$ incubation at $4 \mathrm{mM}, 30 \mathrm{mM}$ glucose or 4 $\mathrm{mM}$ glucose $+26 \mathrm{mM}$ mannitol, respectively.

We investigated first whether the increased level of glucose modulates the incorporation of ${ }^{3} \mathrm{H}-$ glucosamine in HA of the medium, matrix and cellassociated compartments of HMC cultures. It is seen

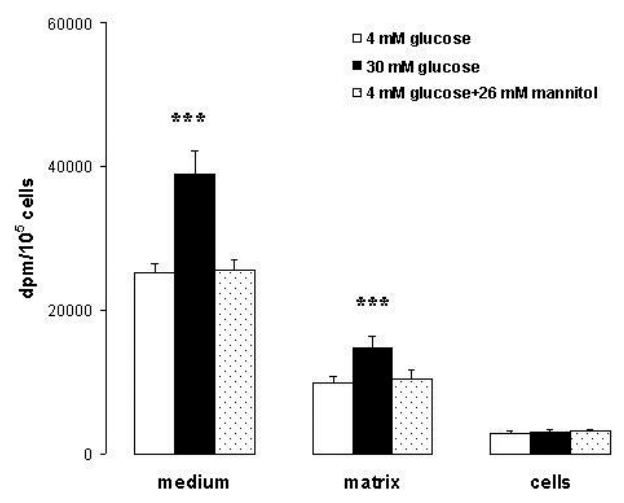

Figure 1. Incorporation of $\left[{ }^{3} \mathrm{H}\right]$ glucosamine in hyaluronic acid (HA) of medium, matrix and cell layer compartments of HMC cultures.

Cells were metabolically labeled with $10 \mu \mathrm{Ci} / \mathrm{ml} \mathrm{D}-[1-$ ${ }^{3} \mathrm{H}$ ]glucosamine for $24 \mathrm{~h}$ in serum-deprived RPMI 1640 medium, supplemented with $4 \mathrm{mM}$ glucose, $30 \mathrm{mM}$ glucose or $4 \mathrm{mM}$ glucose $+26 \mathrm{mM}$ mannitol. The isolation of $\left[{ }^{3} \mathrm{H}\right] \mathrm{HA}$ is described under Materials and Methods. Data are expressed as mean \pm S.E. of 3 independent experiments in triplicate. ${ }^{* *}$ Significant at $P<0.01$. 
(Fig. 1) that the incorporation of $\left[{ }^{3} \mathrm{H}\right]$ glucosamine was increased (about 1.5-fold) both in the medium and matrix HA of cultures treated with $30 \mathrm{mM}$ glucose in comparison to control ones. No difference was observed in the cell-associated compartment. Cells treated with $4 \mathrm{mM}$ glucose $+26 \mathrm{mM}$ mannitol did not differ from control cells by all indices.

The analysis of $\left[{ }^{3} \mathrm{H}\right] \mathrm{HA}$ molecular size distribution indicated that the increase of HA accumulation in the medium (Fig. 2A) and matrix (Fig. 2B) compartments was caused only by the augmentation of high-molecular-weight (HMW) fraction $(>2000 \mathrm{kDa})$. This fraction of the HA molecules increased from $73.7 \pm 2.3 \%(\mathrm{n}=8)$ to $85.7 \pm 3.0 \%(\mathrm{n}=8)$, $P<0.02$, in the medium and from $71.6 \pm 2.7 \%(\mathrm{n}=8)$ to $83.0 \pm 2.7 \%(n=8), P<0.02)$ in the matrix, under the action of $30 \mathrm{mM}$ glucose. The levels of middle (between 2000 and $100 \mathrm{kDa}, \mathrm{MMW}$ ) and low

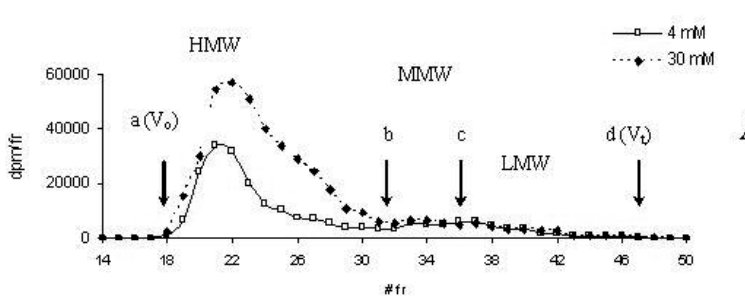

A
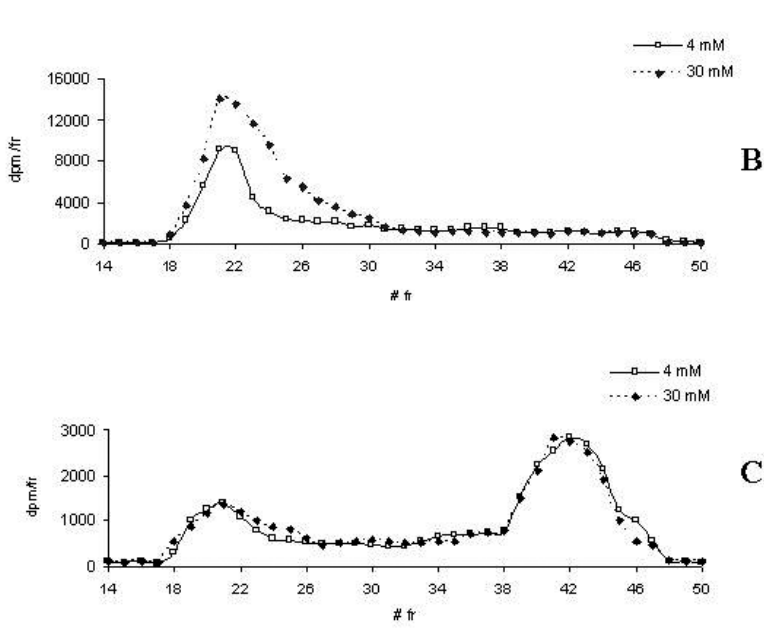

Figure 2. A typical example of molecular size distribution of $\left[{ }^{3} \mathrm{H}\right] \mathrm{HA}$ in the different compartments of HMC cultures treated with $30 \mathrm{mM}$ glucose.

Cells were incubated and labeled as in Fig. $1\left[{ }^{3} \mathrm{H}\right] \mathrm{HA}$ was isolated from medium (panel A), matrix (panel B) and cell layer (panel C) compartments of HMC cultures and chromatographed on a $1 \times 30-\mathrm{cm}$ Sephacryl S1000 column. Elution was carried out as described under Materials and Methods. Arrows mark the positions of the compounds used for column calibration: a (Healon $\mathrm{GV}, 7000 \mathrm{kDa}$ ) at fraction 18, b (blue dextran, $2000 \mathrm{kDa}$ ) at fraction 31, c (decorin, $100 \mathrm{kDa}$ ) at fraction 36, and d $\left(\left[{ }^{3} \mathrm{H}\right]\right.$ glucosamine hydrochloride, $\left.215 \mathrm{Da}\right)$ at fraction 47. Three arbitrary size brackets of HA are indicated, high molecular weight (HMW), >2000 kDa; middle (MMW), 100-2000 kDa; and low (LMW), <100 kDa.
$(<100 \mathrm{kDa}, \mathrm{LMW})$ molecular weight HA were not changed.

In the cell-associated compartment of HMC cultures we did not detect any alterations of molecular size distribution (Fig. 2C), the HMW fraction being about $32.5 \%$, the MMW fraction about $11.2 \%$ and the LMW fraction about $56.3 \%$, both at $4 \mathrm{mM}$ and $30 \mathrm{mM}$ glucose. Such a distribution of HA molecules with different molecular weights in medium, matrix and cell-associated compartments of HMC cultures could hardly has been caused by alterations of HA degradation under high glucose treatment.

To confirm this suggestion we investigated the functional capacity of HMC cells to degrade exogenously added HMW $\left[{ }^{3} \mathrm{H}\right] \mathrm{HA}$ at $4 \mathrm{mM}$ and 30 $\mathrm{mM}$ glucose. There was no difference between the elution profiles of exogenous $\left[{ }^{3} \mathrm{H}\right] \mathrm{HA}$ in the medium of HMC cultures treated or not with $30 \mathrm{mM}$ glucose after $24 \mathrm{~h}$ (Fig. 3A) or $72 \mathrm{~h}$ (Fig. 3B) of incubation. Thus, the degradation of exogenous HA by HMC cells was the same at $4 \mathrm{mM}$ and $30 \mathrm{mM}$ glucose.

In order to clarify the role of TGF $\beta 1$ and its activation by TSP-1 in the high glucose-induced alterations of HA synthesis by HMCs we did the following. At first, we detected the level of total and active TGF $\beta 1$ and TSP- 1 concentration in the conditioned

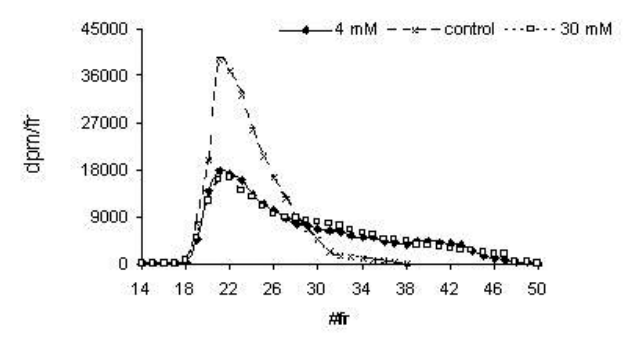

A

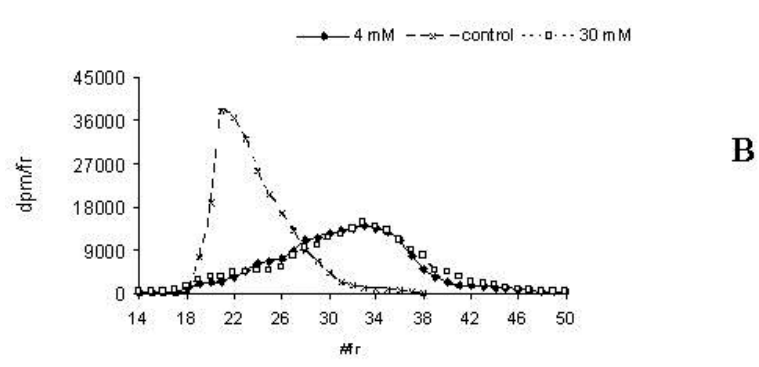

Figure 3. Incubation of exogenous $\left[{ }^{3} \mathrm{H}\right] \mathrm{HA}$ with HMC cultures.

Fibroblast-generated HMW [ $\left.{ }^{3} \mathrm{H}\right] \mathrm{HA}$ (about 250000 d.p.m.) was added to HMC cultures, which were then incubated in serum-deprived medium at $4 \mathrm{mM}$ or $30 \mathrm{mM}$ glucose for $24 \mathrm{~h}$ (panel A) or $72 \mathrm{~h}$ (panel B). The HA size distribution in the medium fraction was examined by Sephacryl S-1000 chromatography as described under Materials and Methods. The data were corrected for cell number. The elution profile of the original HMW $\left[{ }^{3} \mathrm{H}\right] \mathrm{HA}$, which was incubated without cells, is demonstrated for comparison. 
Table 1. Concentrations of total and active TGF $\beta 1$ and TSP-1 ( $\mathrm{ng} / \mathrm{ml}$ per $10^{4}$ cells) in the conditioned medium of human mesangial cells (HMC)

\begin{tabular}{|c|c|c|c|c|}
\hline & $4 \mathrm{mM}$ glucose & $30 \mathrm{mM}$ glucose & $\begin{array}{l}30 \mathrm{mM} \text { glucose + } \\
\text { W-peptide }\end{array}$ & $\begin{array}{l}30 \mathrm{mM} \text { glucose }+ \\
\text { Y-peptide }\end{array}$ \\
\hline Total TGF $\beta 1$ & $\begin{array}{l}1.55 \pm 0.06 \\
(\mathrm{n}=6)\end{array}$ & $\begin{array}{l}2.21 \pm 0.21^{* *} \\
(\mathrm{n}=6)\end{array}$ & $\begin{array}{l}2.27 \pm 0.23^{* *} \\
(\mathrm{n}=4)\end{array}$ & $\begin{array}{l}2.20 \pm 0.19^{* *} \\
(\mathrm{n}=4)\end{array}$ \\
\hline Active TGF $\beta 1$ & $\begin{array}{l}0.074 \pm 0.006 \\
(n=6)\end{array}$ & $\begin{array}{l}0.152 \pm 0.14^{* *} \\
(\mathrm{n}=6)\end{array}$ & $\begin{array}{l}0.082 \pm 0.008 \\
(\mathrm{n}=4)\end{array}$ & $\begin{array}{l}0.159 \pm 0.015^{* * *} \\
(\mathrm{n}=4)\end{array}$ \\
\hline TSP-1 & $\begin{array}{l}6.24 \pm 0.61 \\
(\mathrm{n}=6)\end{array}$ & $\begin{array}{l}10.01 \pm 1.01^{* * *} \\
(\mathrm{n}=6)\end{array}$ & $\begin{array}{l}11.12 \pm 1.11^{* * *} \\
(\mathrm{n}=4)\end{array}$ & $\begin{array}{l}10.49 \pm 1.11^{* *} \\
(\mathrm{n}=4)\end{array}$ \\
\hline
\end{tabular}

HMCs were incubated under $4 \mathrm{mM}$ or $30 \mathrm{mM}$ glucose and under $30 \mathrm{mM}$ glucose $+1 \mu \mathrm{M}$ synthetic TSP-derived GGWSHW peptide (Wpeptide) or GGYSHW peptide (Y-peptide) in RPMI 1640 medium, containing 10\% FCS. After $24 \mathrm{~h}$ the medium was changed to a serumfree one with the corresponding amounts of glucose and peptides. In $24 \mathrm{~h}$ of additional incubation the levels of total and active TGF $\beta 1$ were determined by the MvILu cell growth inhibition assay and TSP-1 level was determined by ELISA, as described in Materials and Methods. Data are expressed as means \pm S.E. ${ }^{* * *}$ Significant at $P<0.01, * *$ significant at $P<0.02$, as compared to $4 \mathrm{mM}$ glucose.

medium of HMC cultures under $30 \mathrm{mM}$ glucose. It is seen (Table 1) that a $48 \mathrm{~h}$ incubation of HMCs increased the level of total (1.43-fold) and active (2.05fold) TGF $\beta 1$, and the level of TSP-1 (1.6-fold), and corresponded to the results obtained earlier with a more prolonged high glucose treatment (Yevdokimova et al., 2001). Then, we demonstrated that the blockage of TGF $\beta 1$ action with an anti-TGF $\beta 1$ neu-

A

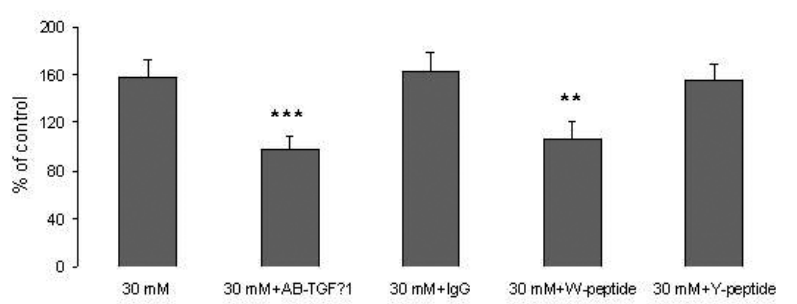

B

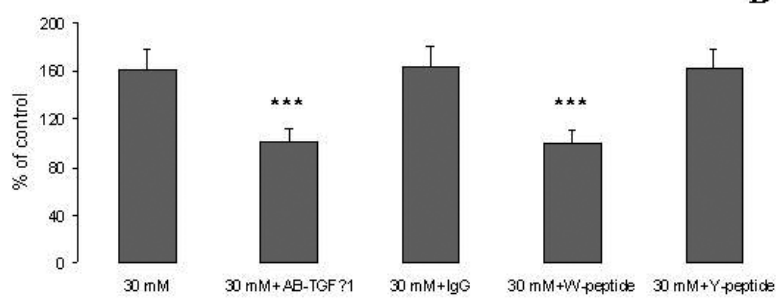

Figure 4. Effect of the blockage of endogenous TGF $\beta 1$ action on the generation of $\left[{ }^{3} \mathrm{H}\right] \mathrm{HA}$ by high glucosetreated HMC cultures.

The incubation medium, apart from $30 \mathrm{mM}$ glucose, contained: (i) $30 \mu \mathrm{g} / \mathrm{ml}$ of anti-TGF $\beta 1$ neutralizing antibody (AB-TGF $\beta 1$ ) or non-specific IgG or (ii) $1.0 \mu \mathrm{M}$ of the synthetic TSP-derived GGWSHW peptide (W-peptide) or GGYSHW peptide (Y-peptide). The labeling and isolation of $\left[{ }^{3} \mathrm{H}\right] \mathrm{HA}$ from medium (panel A) and matrix (panel B) compartments of HMC cultures were done as described under Materials and Methods. Data represent percentage of the control (4 mM glucose) for each sample and are expressed as means \pm S.E. from 3 independent experiments in triplicate. ${ }^{* * *}$ Significant at $P<0.01,{ }^{* *}$ significant at $P<$ 0.02 , as compared to $30 \mathrm{mM}$ glucose. tralizing antibody $(30 \mu \mathrm{g} / \mathrm{ml})$ abolished the high glucose-induced alterations of $\left[{ }^{3} \mathrm{H}\right]$ glucosamine incorporation in medium (Fig. 4A) and matrix HA (Fig. 4B), whereas non-specific IgG was ineffective. We observed also the normalization of the molecular size distribution of medium and matrix $\left[{ }^{3} \mathrm{H}\right] \mathrm{HA}$ with anti-TGF $\beta 1$ neutralizing antibody (not shown).

We investigated next whether the increased production of HA by HMC cultures treated with high glucose was dependent on TSP-1 activation of TGF $\beta 1$. The classic mechanism of TGF $\beta 1$ activation (Schultz-Cherry et al., 1995) consists in a two-step interaction of TSP- 1 molecule with the latent TGF $\beta 1$ complex leading to the liberation of active cytokine. The initial step of this process is the binding of the specific amino-acid sequence GGWSHW of the TSP1 molecule to the mature part of latent TGF $\beta 1$ complex. An excess of synthetic GGWSHW peptide (Wpeptide) blocks TGF $\beta 1$ activation, whereas, synthetic GGYSHW (Y-peptide) is ineffective, and may serve as a control. In a previous work (Yevdokimova et al., 2001) we used this approach, established the optimal concentration of $\mathrm{W}$-peptide $(1.0 \mu \mathrm{M})$, observed the abolishment of the excessive high glucose-induced activation of TGF $\beta 1$, and the normalization of excessive production of ECM proteins by HMC cultures treated with high glucose. The level of total TGF $\beta 1$ and TSP- 1 did not alter under W-peptide treatment in all the studied range of concentrations (0.01-10 $\mu \mathrm{M})$. In the present work, we confirmed the rationality of this approach, and demonstrated that the employment of $1.0 \mu \mathrm{M} \mathrm{W}$-peptide normalized the increased $\left[{ }^{3} \mathrm{H}\right]$ glucosamine incorporation in medium (Fig. 4A) and matrix (Fig. 4B) HA due to the blockage of TSP-1-dependent TGF $\beta 1$ activation (Table 1).

For further verification of the possible role of TGF 1 in mediating the high glucose effect on HA metabolism we used the incubation of control HMCs with exogenous human TGF $\beta 1$. Figure 5A demonstrates the dose dependence of $\left[{ }^{3} \mathrm{H}\right]$ glucosamine incorporation in matrix HA. Based on these data, we chose $4.0 \mathrm{ng} / \mathrm{ml}$ for further work. It is seen that ex- 
A elution profile was observed for the chromatography

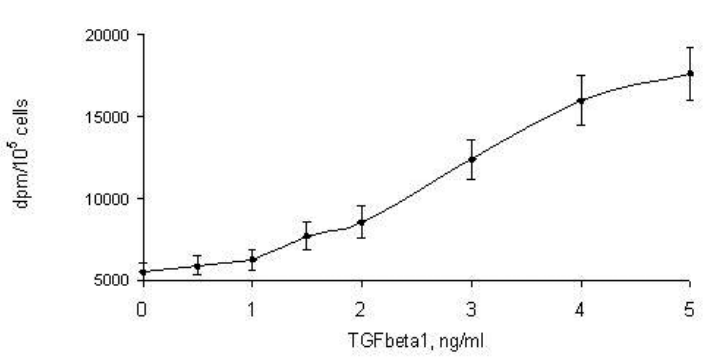

B

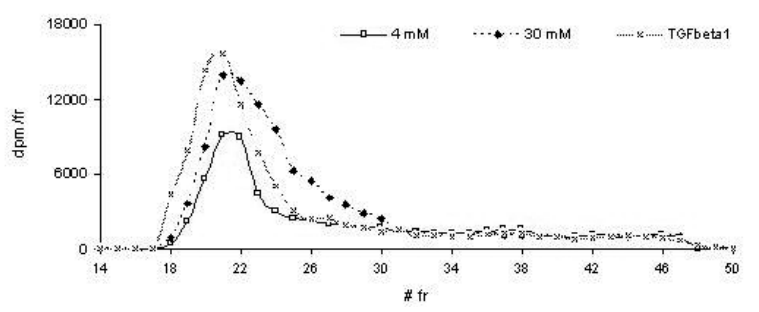

Figure 5. Effect of exogenous human platelet TGF $\beta 1$ on the accumulation and molecular size distribution of $\left[{ }^{3} \mathrm{H}\right] \mathrm{HA}$ in the matrix compartment of HMC cultures. Panel A. Cells were exposed to increasing concentration of TGF $\beta 1(0-5 \mathrm{ng} / \mathrm{ml})$ for $48 \mathrm{~h}$. The isolation of $\left[{ }^{3} \mathrm{H}\right] \mathrm{HA}$ from matrix fraction was carried out as described in Materials and Methods. Data are expressed as means \pm S.E. of 2 experiments in triplicate. Panel B. The $\left[{ }^{3} \mathrm{H}\right] \mathrm{HA}$ was isolated from the matrix compartment of HMC cultures treated with $4 \mathrm{ng} / \mathrm{ml}$ TGF $\beta 1$ and loaded on Sephacryl S1000 column. The elution profiles of $\left[{ }^{3} \mathrm{H}\right] \mathrm{HA}$ from control and high glucose-treated cultures are demonstrated for the comparison. The chromatography was carried out as described under Materials and Methods.

ogenous human TGF $\beta 1$ increased the incorporation of $\left[{ }^{3} \mathrm{H}\right]$ glucosamine in matrix HA and altered its molecular size distribution (Fig. 5B), resembling the effect of high glucose. TGF $\beta 1$ increased the HMW part of HA molecules to $84.6 \pm 4.5 \%(n=4)$, not influencing the amount of MMW and LMW HA. A similar

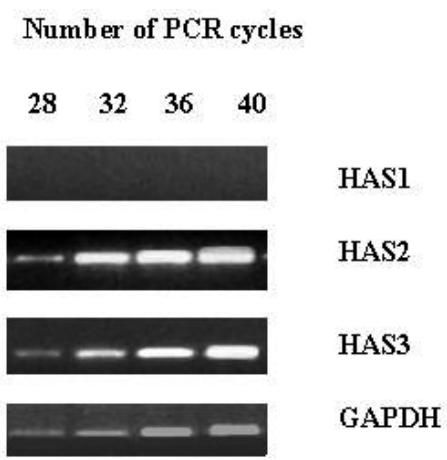

Figure 6. A typical example of PCR cycle-dependent amount of RT-PCR products of HAS1, HAS2, HAS3 and GAPDH mRNAs.

The description of RT-PCR experiments is under Materials and Methods. of medium HA, whereas TGF $\beta 1$ did not alter the $\left[{ }^{3} \mathrm{H}\right]$ glucosamine incorporation in the cell-associated fraction of HMC cultures (not shown). Hence, both high glucose and TGF $\beta 1$ not only stimulated the HA production, but altered the molecular size distribution, increasing the percentage of HMW molecules in the medium and matrix fraction. This confirmed the likely participation of TGF $\beta 1$ in the mediating of high glucose effect on HA metabolism.

To determine if a specific HAS isoform is involved in the high glucose-induced HA synthesis we investigated the expression of mRNAs of HAS1, HAS2 and HAS3 by semi-quantitative RT-PCR. Specific PCR products for HAS2, HAS3 and GAPDH were detected following 28 cycles, whereas a HAS1

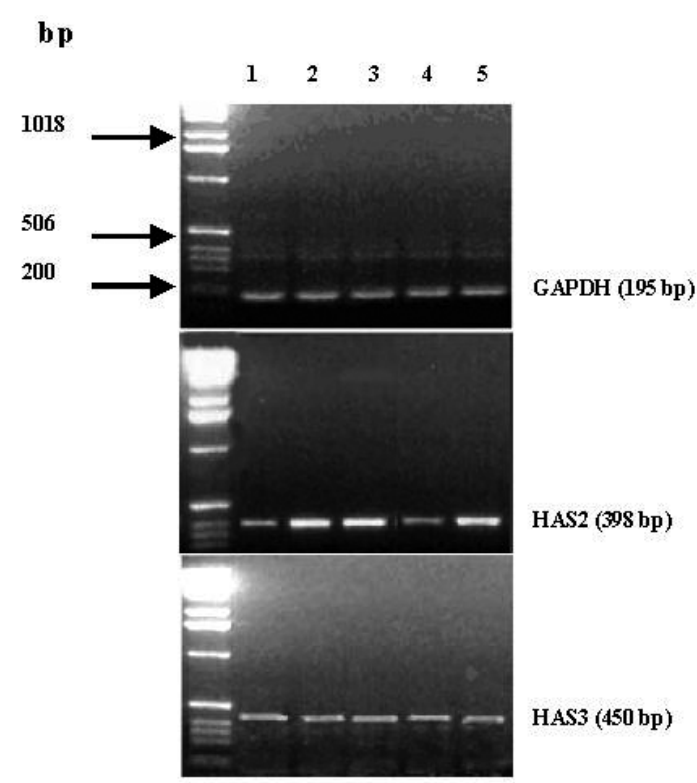

A

B $\square 4 \mathrm{mM}=30 \mathrm{mM}$ घGFbeta1 $830 \mathrm{mM}+W \square 30 \mathrm{mM}+Y$

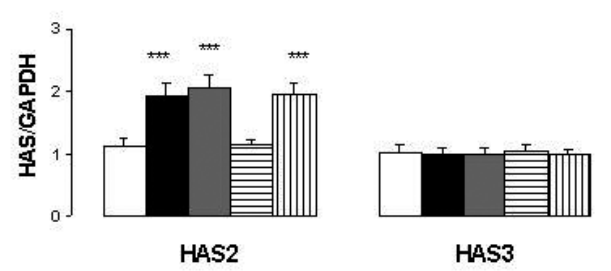

Figure 7. Expression of GAPDH, HAS2 and HAS3 mRNAs of HMC cultures measured by RT-PCR.

Panel A. An example of RT-PCR product electrophoresis: lane 1, $4 \mathrm{mM}$ glucose; lane 2, $30 \mathrm{mM}$ glucose; lane 3, exogenous TGF $\beta 1$; lane $4,30 \mathrm{mM}$ glucose $+\mathrm{W}$-peptide; lane $5,30 \mathrm{mM}$ glucose + Y-peptide. The description of HMCs incubation and RT-PCR experiments are under Materials and Methods. Panel B. The ratio of the fluorescence of HAS2 and HAS3 bands to the fluorescence of GAPDH bands at different experimental conditions. Data are expressed as means \pm S.E. of 3 independent experiments in duplicate. ${ }^{* *}$ Significant at $P<0.01$ compared to $4 \mathrm{mM}$ glucose. 
PCR product could not be detected even after $40 \mathrm{cy}$ cles. The expression of HAS1 mRNA has previously been demonstrated in human fibroblast-like synoviocytes by Stuhlmeier and Pollaschek (2004) and in human dermal fibroblasts by us (not shown) to confirm the efficacy of the primers used.

The linearity of amplification of PCR products for HAS2, HAS3 and GAPDH was observed throughout $28-40$ cycles (Fig. 6). We used 33 cycles for further investigations, terminating the reaction in an early log-phase of product accumulation.

The expression of HAS2 mRNA was increased in cells exposed to $30 \mathrm{mM}$ glucose and to exogenous human TGF $\beta 1$, comparatively to control cells (Fig. 7A). A densitometric analysis of HAS2 bands, corrected for GAPDH bands (Fig. 7B), showed an increase of 1.72 -fold and of 1.82 -fold, for $30 \mathrm{mM}$ glucose and TGF $\beta 1$, respectively. The addition of the blocking peptide $\mathrm{W}$ to high glucose medium abolished the up-regulation of HAS2 mRNA expression, whereas the control peptide $\mathrm{Y}$ was ineffective. The expression of HAS3 mRNA did not change under either of the treatments used.

\section{DISCUSSION}

HA is a linear polymer of glucuronic acid and $\mathrm{N}$-acetylglucosamine disaccharide with alternating $\beta-1,4$ and $\beta-1,3$ glycosidic bonds (Laurent \& Fraser, 1992). HA is synthesized by the HA synthases (HAS1, HAS2 and HAS3) at the inner side of the plasma membrane, and directly secreted into the extracellular space. It is composed, on average, of 10000-30000 disaccharide units, with a molecular mass about 4000$10000 \mathrm{kDa}$. HAS1 and HAS2 produce HA chains of a similar large size $(>2000 \mathrm{kDa})$, whereas HAS3 synthesizes shorter chains (100-300 kDa) (Tammi et al., 2001; Noble, 2002). The expression of each of these enzymes is cell-type-specific, and each enzyme is regulated differentially in response to external stimuli (Jacobson et al., 2000). HA is cleaved into fragments of low and intermediate molecular weight by specific hyaluronidases, or via the action of reactive oxygen species. The regulation of hyaluronidase activity and the expression of their various isoforms is poorly understood, although it is one of the most important points in the HA role for tissue homeostasis, because HA degradation products have biological functions distinct from those of the native HMW polymer (Noble, 2002).

Some HA functions are connected to its role as an integral and central part of ECM of various tissues. Its unique physicochemical properties are involved in the regulation of cell behavior due to the ability of influencing the cell environment via the interaction with cells and other components of ECM.
Besides, HA and its oligosaccharides may directly affect cell function through binding to its receptor (CD44) and altering specific gene expression.

At present, it is obvious that HA is essential for tissue homeostasis (Tammi et al., 2001) and for kidney in particular. Nevertheless, although the implication of HA in the regulation of protein and water balance in the kidney was detected already in the fifties (Ginetzinsky, 1958) and many recent works (Wells et al., 1993; Hascall et al., 2004; Asselman et al., 2005) demonstrated an association between HA metabolism and renal injury diseases, the role of this link is not completely clear yet. As to the development of diabetic nephropathy, the comprehension of HA importance began, possibly, from the observation about increased HA synthesis within the glomeruli of diabetic rat kidney (Mahadevan et al., 1995).

In the present work we demonstrated that high glucose stimulates the accumulation of HA in the medium and matrix compartments of HMC cultures without any alterations in the cell-associated compartment. The increase of $\left[{ }^{3} \mathrm{H}\right]$ glucosamine incorporation in medium and matrix HA was the same, and was caused only by the incorporation in high-molecular-weight molecules, hence, the redistribution of HA molecules between medium and matrix did not take place. Besides, the ability of mesangial cells to degrade exogenous HA did not depend on the glucose concentration in the medium. Therefore, we consider that high glucose did not stimulate HA degradation in human mesangial cells. This result is in line with the observed formation of pericellular HA cable-like structures in high glucoseinduced rat mesangial cells (Wang \& Hascall, 2004). An increased synthesis of HA due to high glucose was demonstrated also in another work dealing with rat mesangial cells (Dunlop et al., 1996), for primary cultures of human renal proximal tubular epithelial cells (PTC) and an immortal cell line HK-2 obtained from PTCs (Jones et al., 2001), and for a normal rat kidney fibroblast cell line (Takeda et al., 2001).

This effect is D-glucose-specific and not due to an osmotic effect, as the replacement of D-glucose by mannitol (in our investigations) or L-glucose does not cause a similar response.

According to our data, the cause of the increased production of HMW HA consisted in the up-regulation of HAS2 mRNA expression without alterations of the mRNA for HAS3, which produces HA of lower molecular weight. These data are in agreement with the response of PTCs and HK-2 cells to elevated glucose level (Jones et al., 2001).

It should be noted that we were not able to detect the expression of HAS1 mRNA at either normal or high glucose conditions. HAS1 mRNA was undetectable also in PTCs and HK-2 cells (Jones et 
al., 2001; Selbi et al., 2004; Asselman et al., 2005), and in Madine-Darby canine kidney cells (Asselman et al., 2005). Therefore, the synthesis of high molecular weight HA in kidney seems to be determined mainly by HAS2, which almost obligatorily is involved in HA metabolic alterations in various renal pathological processes (Göransson et al., 2004), including diabetic nephropathy.

Human TGF $\beta 1$ up-regulated the expression of HAS2 mRNA and had no effect on HAS3 expression. We already mentioned that the regulation of HAS genes is poorly understood and is celltype specific (Jacobson et al., 2000). Nevertheless, it should be noted that the influence of TGF $\beta 1$ mainly leads to the up-regulation of HAS2 or/and HAS1 mRNAs, whereas HAS3 remains unaltered, or even is down-regulated. For example, TGF $\beta 1$ up-regulated: (a) both HAS1 and HAS2 in human skin cells (Sugiyama et al., 1998); (b) HAS1 in human mesothelial cells (at the level of protein expression also) (Jacobson et al., 2000), in human synovial (Recklies et al., 2001; Oguchi \& Ishiguro, 2004) and vascular endothelial cells (Suzuki et al., 2003); (c) HAS1 with simultaneous down-regulation of HAS3 in human synovial cells (Stuhlmeier \& Pollaschek, 2004); (d) HAS2 in rabbit fibroblasts from the synovial membrane of the temporomandibular joint (Tanimoto et al., 2004), in bovine corneal endothelial cells (Usui et al., 2000) and meshwork cells (Usui et al., 2003) (for both at the level of protein also). Besides, bone morphogenic protein-7 (BMP-7), which belongs to the TGF $\beta$ family, up-regulated HAS2 mRNA, had no effect on HAS3 expression and increased the synthesis of only HMW HA in HK-2 cells (Selbi et al., 2004). These investigations allow suggesting that TGF $\beta 1$ is able to enhance the synthesis of only HMW HA molecules by selective up-regulation of HAS1 and HAS2.

According to our results, TGF $\beta 1$ indeed increased the incorporation of $\left[{ }^{3} \mathrm{H}\right]$ glucosamine only in HMW HA of mesangial cells, and its effect was similar to the action of high glucose, which up-regulated the expression of HAS2 mRNA, did not influence HAS3 mRNA and stimulated the generation of high-molecular-weight HA. These results lend credit to an involvement of TGF $\beta 1$ in the high glucose-induced alterations of HA metabolism, the more so as an anti-TGF $\beta 1$-neutralizing antibody completely abolished the effect of high glucose on HA accumulation and molecular size distribution in the medium and matrix compartments of mesangial cultures. An involvement of TGF $\beta 1$ in the modulation of HA synthesis by high glucose was demonstrated for renal intestinal fibroblasts (Takeda et al., 2001), and our results confirmed those data.

The blockage of TSP-dependent activation of TGF $\beta 1$ with $\mathrm{W}$-peptide normalized the high glucose- induced expression of HAS2 mRNA and simultaneously normalized the increased HA production.

It seems that such an effect of the blockage of TSP-1-dependent TGF $\beta 1$ activation not only supports the proposed involvement of TGF $\beta 1$ in the high-glucose action on HA metabolism in HMC cultures, but suggests an important role of endogenous TSP-1 with respect to regulation of HA metabolism, as it was recently demonstrated for the inflammation process in TSP-1-deficient mice (Kuznetsova et al., 2005).

As to the role of the increased generation of HA in HMCs treated by high glucose, it remains not clear whether this phenomenon provides a promotional, passive or defensive function in the development of diabetic nephropathy. On the one hand, HA-enriched mesangial ECM stimulates monocyte and macrophage adhesion (Wang \& Hascall, 2004), formally promoting the inflammatory response and progression of diabetic nephropathy. On the other hand, HA cable-like structures, which bind monocytes, keep these cells away from the proinflammatory adhesion molecules (ICAM-1/VCAM-1) on the surface of mesangial cells. Hence, they may prevent the interaction of mesangial ICAM-1/VCAM-1 with the corresponding leukocyte counter-receptors and generation of the inflammatory cytokines (van Kooten et al., 1999). Moreover, it should be noted that ICAM1-deficient mice with streptozotocin diabetes demonstrated decreased macrophage infiltration, albumin excretion, glomerular hypertrophy, mesangial ECM expansion and even down-regulation of TGF $\beta 1$ and collagen IY compared with diabetic wild type mice (Okada et al., 2003). This observation suggests that the limitation of the direct contact between mesangial cells and monocytes/macrophages due to cell-associated HA cables (which mainly contain HMW HA) may in fact slow down the development of diabetic nephropathy, despite the commonly held belief that diabetic nephropathy is not an inflammatory condition.

Besides, HMW HA inhibits the activity of TGF $\beta 1$ (Locci et al., 1995) and stimulates the secretion of tissue inhibitors of metalloproteinases (Yasui et al., 1992), therefore revealing anti-fibrotic functions.

Thus, it seems that high-molecular-weight HA may provide a defensive role, representing an endogenous mechanism to limit renal injury and the development of diabetic nephropathy.

Overall, our results indicate that high glucose treatment of human mesangial cells leads to an increased synthesis of HA of high molecular weight. This effect is determined by the up-regulation of HAS2 and is mediated via the TSP-1-dependent activation of TGF $\beta 1$. 


\section{Acknowledgements}

This research was supported by the National Academy of Sciences of Ukraine, the Wellcome Trust Travelling Research Grant Z180/99 and by grant F7/480 of the Ministry of Education and Science of Ukraine.

\section{REFERENCES}

Asselman M, Verhulst A, Van Ballegoijen ES, Bangma $\mathrm{CH}$, Verkoelen CF, De Broe ME (2005) Hyaluronan is apically secreted and expressed by proliferating or regenerating renal tubular cells. Kidney Int 68: 71-83.

Breborowicz A, Korybalska K, Grzybowski A, Wieczorowska-Tobis K, Martis L, Oreopoulos DG (1996) Synthesis of hyaluronic acid by human peritoneal mesothelial cells: effect of cytokines and dialysate. Perit Dial Int 16: 4-8.

Crawford SE, Stellmach V, Murphy-Ullrich JE, Ribiero SMF, Lawler J, Hynes RO, Boivin GP, Bouk N (1998) Thrombospondin-1 is a major activator of TGF $\beta 1$ in vivo. Cell 93: 1151-1163.

Dunlop ME, Clark S, Mahadevan P, Muggli E, Larkins RE (1996) Production hyaluronan by glomerular mesangial cells in response to fibronectin and platelet-derived growth factor. Kidney Int 50: 40-44.

Ellis IR, Schor SL (1998) Differential motogenic and biosynthetic response of fetal and adult skin fibroblasts to TGF-beta isoforms. Cytokine 10: 281-289.

Ginetzinsky AG (1958) Role of hyaluronidase in the re-absorption of water in renal tubules. Nature 182: 12181222.

Göransson V, Johnsson C, Jakobson A, Heldin P, Hällgren R, Hansell P (2004) Renal hyaluronan accumulation and hyaluronan expression after ischaemia-reperfusion injury in the rat. Nephrol Dial Transplant 19: 823-830.

Hascall VC, Majors AK, De La Motte CA, Evanko SP, Wang A, Drazba JA, Strong SA, Wight TN (2004) Intracellular hyaluronan: a new frontier for inflammation? Biochim Biophys Acta 1673: 3-12.

Haubeck HD, Kock R, Fisher DC, Van der Leur E, Hoffmeister K, Greiling H (1995) Transforming growth factor beta1, a major stimulator of hyaluronan synthesis in human synovial lining cells. Arthritis Rheum 38: 669-677.

Heldin P, Laurent TC, Heldin C-H (1989) Effect of growth factors on hyaluronan synthesis in cultured human fibroblasts. Biochem J 258: 919-922.

Hugo C (2003) The thrombospondin 1 - TGF- $\beta$ axis in fibrotic renal disease. Nephrol Dial Transplant 18: 12411245.

Jacobson A, Brinck J, Briskin MJ, Spicer A, Heldin P (2000) Expression of human hyaluronan synthases in response to external stimuli. Biochem J 348: 29-35.

Jones S, Jones S, Phillips AO (2001) Regulation of renal proximal tubular epithelial cell hyaluronan generation: implications for diabetic nephropathy. Kidney Int 59: 1739-1749.

Kuznetsova SA, Day AJ, Mahoney DJ, Rugg MS, Mosher DF, Roberts DD (2005) The N-terminal module of thrombospondin-1 interacts with the link domain of TSG-6 and enhances its covalent association with the heavy chains of inter-alpha-trypsin inhibitor. J Biol Chem 280: 30899-30908.
Laurent TC, Fraser JRE (1992) Hyaluronan. FASEB J 6: 2397-2404.

Locci P, Marinucci L, Lilli C, Martinese D, Becchetti E (1995) Transforming growth factor $\beta 1$ - hyaluronic acid interaction. Cell Tissue Res 281: 317-324.

Mahadevan P, Larkins RG, Fraser JR, Fosang AJ, Dunlop ME (1995) Increased hyaluronan production in the glomeruli from diabetic rats: a link between glucoseinduced prostaglandim production and reduced sulphated proteoglycan. Diabetologia 38: 298-305.

McLennan SV, Death AK, Fisher EJ, Williams PF, Yue DK, Turtle JR (1999) The role of the mesangial cell and its matrix in the pathogenesis of diabetic nephropathy. Cell Mol Biol 45: 123-135.

Noble PW (2002) Hyaluronan and its catabolic products in tissue injury and repair. Matrix Biology 21: 25-29.

Oguchi T, Ishiguro N (2004) Differential stimulation of three forms of hyaluronan synthase by TGF-beta, IL1beta and TNF-alpha. Connect Tissue Res 45: 197-205.

Okada S, Shikata K, Matsuda M, Ogawa D, Usui H, Kido Y, Nagase R, Wada J, Shikata Y, Makino H (2003) Intercellular adhesion molecule-1-deficient mice are resistant against renal injury after induction of diabetes. Diabetes 52: 2586-2593.

Poczatek MH, Hugo Ch, Darley-Usmar V, Murphy-Ulrich JE (2000) Glucose stimulation of transforming growth factor- $\beta$ bioactivity in mesangial cells is mediated by thrombospondin 1. Am J Pathol 157: 1353-1363.

Recklies AD, White C, Melching L, Roughley P (2001) Differential regulation and expression of hyaluronan synthases in human articular chondrocytes, synovial cells and osteosarcoma cells. Biochem J 354: 17-24.

Schultz-Cherry S, Chen H, Mosher DF, Misenheimer TM, Krutzsch HC, Roberts DD, Murphy-Ulrich JE (1995) Regulation of transforming growth factor- $\beta$ activation by discrete sequences of thrombospondin 1 . J Biol Chem 270: 7304-7310.

Selbi W, De La Motte C, Hascall V, Phillips A (2004) BMP7 modulates hyaluronan-mediated proximal tubular cell-monocyte interaction. J Am Soc Nephrol 15: 11991211.

Stuhlmeier KM, Pollaschek C (2004) Differential effect of transforming growth factor $\beta$ (TGF- $\beta$ ) on the genes encoding hyaluronan synthases and utilization of the p38 MAPK pathway in TGF- $\beta$-induced hyaluronan synthase 1 activation. J Biol Chem 279: 8753-8760.

Sugiyama Y, Shimada A, Sayo T, Sakai S, Inoue S (1998) Putative hyaluronan synthase mRNAs are expressed in mouse skin and TGF-beta upregulates their expression in cultured human skin cells. J Invest Dermatol 110: 116-121.

Suzuki K, Yamamoto T, Usui T, Suzuki K, Heldin P, Yamashita $H$ (2003) Expression of hyaluronan synthase in intraocular proliferative diseases: regulation of expression in human vascular endothelial cells by transforming growth factors- $\beta$. Jpn J Ophtalmol 47: 557-564.

Takeda M, Babazono T, Nitta K, Iwamoto Y (2001) High glucose stimulates hyaluronan production by renal intestinal fibrolasts through the protein kinase $\mathrm{C}$ and transforming growth factor- $\beta$ cascade. Metabolism 50: 789-794.

Tammi MI, Day AJ, Turley EA (2001) Hyaluronan and homeostasis: a balancing act. J Biol Chem 277: 45814584 .

Tanimoto K, Suzuki A, Ohno S, Honda K, Tanaka N, Doi $\mathrm{T}$, Yoneno K, Ohno-Nakahara M, Nakatani Y, Ueki M, Tanne K (2004) Effects of TGF- $\beta$ on hyaluronan anabolism derived from the synovial membrane of the rabbit temporomandibular joint. J Dent Res 83: 40-44. 
Usui T, Amano S, Tetsuro O, Suzuki K, Miyata K, Araie M, Heldin P, Yamashita H (2000) Expression regulation of hyaluronan synthase in corneal endothelial cells. Invest Ophtalmol Vis Sci 41: 3261-3267.

Usui T, Nakajiama F, Ideta R, Kaji Y, Suzuki Y, Araie M, Miyauchi S, Heldin P, Yamashita H (2003) Hyaluronan synthase in trabecular meshwork cells. $\mathrm{Br} J$ Ophthalmol 87: 357-360.

van Kooten C, Daha MR, van Es LA (1999) Tubular epithelial cells: a critical cell type in the regulation of renal inflammatory process. Exp Nephrol 7: 429-437.

Wang A, Hascall VC (2004) Hyaluronan structures synthesized by rat mesangial cells in response to hyperglycemia induce monocyte adhesion. J Biol Chem 279: 10279-10285.

Wells A, Larsson E, Hanas E, Laurent T, Hallgren R, Tufveson G (1993) Increased hyaluronan in acutely rejecting human kidney grafts. Transplantation 55: 1346-1349.

Yasui T, Akatsuka M, Tobetto K, Umemoto J, Ando T, Jamashita K, Hayakawa T (1992) Effects of hyaluronan on the production of stromelysin and tissue inhibitor of metalloproteinase-1 (TIMP-1) in bovine articular chondrocytes. Biomed Res 13: 343-348.

Yevdokimova NYu, Freshney RI (1997) Activation of paracrine growth factor by a heparin sulphate induced by glucocorticoid in A549 lung carcinoma cells. Br J Cancer 76: 281-289.

Yevdokimova NYu, Abdel Wahab N, Mason RM (2001) Thrombospondin-1 is the key activator of TGF- $\beta 1$ in human mesangial cells exposed to high glucose. $J$ Am Soc Nephrol 12: 703-712.

Yevdokimova NYu (2003) High glucose-induced alterations of extracellular matrix of human skin fibroblasts are not dependent on TSP-1-TGF $\beta 1$ pathway. J Diab Complic 17: 355-365.

Ziyadeh FN (2004) Mediators of diabetic kidney disease: the case for TGF- $\beta$ as the major mediator. J Am Soc $\mathrm{Ne}$ phrol 15 (Suppl 1): S55-S57. 